УДК 001.891:[004.921.78:005.921.-022.324-001.341]

Іванова Світлана Миколаївна

кандидат педагогічних наук, завідувач відділу відкритих освітньо-наукових інформаційних систем Інститут інформаційних технологій і засобів навчання НАПН України, м. Київ, Україна

ORCID ID 0000-0002-3613-9202

iv69svetlana@gmail.com

\title{
ПРОБЛЕМА РОЗВИТКУ ІНФОРМАЦІЙНО-ДОСЛІДНИЦЬКОЇ КОМПЕТЕНТНОСТІ НАУКОВИХ І НАУКОВО-ПЕДАГОГІЧНИХ ПРАЦІВНИКІВ 3 ВИКОРИСТАННЯМ ВІДКРИТИХ ЕЛЕКТРОННИХ НАУКОВО-ОСВIТНIХ СИСТЕМ
}

\begin{abstract}
Анотація. Стаття присвячена проблемі розвитку інформаційно-дослідницької компетентності наукових і науково-педагогічних працівників з метою сприяння процесу підвищення якості результатів їх робіт, створенню та використанню відкритих електронних систем для підтримки наукової і освітньої теоретико-методологічної та практичної баз. Уточнено поняття інформаційно-дослідницька компетентність наукових та науковопедагогічних працівників, що визначається як здатність здійснювати 3 використанням IКТ пошук, збирання, опрацювання, аналіз та представлення наукових даних відповідно до методології наукового дослідження, комунікацію, співробітництво та навчання інших, вміння використовувати сервіси електронних науково-освітніх систем для інформаційноаналітичної підтримки науково-педагогічних досліджень, моніторингу та оцінювання наукових результатів, продукування нових суспільно-значущих знань 3 метою впровадження їх у практику освіти та науки. Висвітлено основний зарубіжний досвід щодо впровадження навчальних програм з інформетрії для розвитку інформаційно-дослідницької компетентності наукових та науково-педагогічних працівників. Визначено вплив відкритих електронних науково-освітніх систем на розвиток інформаційно-дослідницької компетентності науково-педагогічних працівників. 3'ясовано, що важливим є виокремлення відкритих електронних науково-освітніх систем, що мають особливий вплив на розвитку цієї компетентності для забезпечення відкритої науки. Серед таких систем особливого значення набувають платформи для створення електронних бібліотек, відкритих електронних конференцій, сервіси для управління науковою бібліографією, моніторингу науково-дослідної діяльності наукових та науково-педагогічних працівників та ін. Визначено, що перспективами дослідження щодо розвитку інформаційно-дослідницької компетентності наукових та науково-педагогічних працівників $є$ розробка для цього процесу методики використання відкритих науково-освітніх систем відповідно до принципів відкритої науки.
\end{abstract}

Ключові слова: інформаційно-комунікаційні технології; відкрита наука; відкриті електронні науково-освітні системи; наукові та науково-педагогічні працівники; інформаційно-дослідницька компетентність; інформетрія.

\section{1. ВСТУП}

Постановка проблеми. Динамічний розвиток інформаційного простору зумовлює зростання вимог до якості та результативності досліджень наукових i науково-педагогічних працівників. Особливого значення при цьому набуває розвиток їхніх вмінь і навичок здійснювати дослідницьку діяльність в умовах активного розвитку інформаційно-комунікаційних технологій (ІКТ). Зростає необхідність у проведенні науково-педагогічних досліджень, що сприяють розробці та впровадженню в освітній простір IКТ; розвитку інформаційно-дослідницької компетентності наукових i науково-педагогічних працівників 3 метою сприяння процесу підвищення якості результатів їх робіт, створенню та використанню відкритих електронних систем для 
підтримки наукової і освітньої теоретико-методологічної та практичної баз, що може забезпечити модернізацію вітчизняної освіти й науки відповідно до світових тенденцій.

Для наукових i науково-педагогічних працівників важливим завданням сьогодення є набуття знань, вмінь та навичок щодо роботи 3 відкритими науковоосвітніми системами, бібліометричними, вебометричними і наукометричними базами даних, каталогами, створення в них авторських профілів та ідентифікаторів, особливостями публікування у вітчизняних та зарубіжних виданнях, підвищення бібліометричних показників. Важливе значення має розвиток компетентності щодо роботи з інформаційними ресурсами в міжнародних інформаційно-аналітичних базах даних «Web of Science» i «Scopus». Тому володіння науковцями інформаційнодослідницькою компетентністю $є$ необхідною умовою успішної професійної діяльності в наукових установах, закладах вищої освіти і закладах післядипломної освіти.

3 огляду на це, використання відкритих електронних науково-освітніх систем надає нові можливості щодо збирання, зберігання, передачі та аналітичного опрацювання даних, оцінювання публікаційної активності науковців, рівня ефективності їх наукової діяльності та ін. [1].

Аналіз останніх досліджень і публікацій. Проблемі розвитку дослідницької компетентності науково-педагогічних працівників присвячені роботи вітчизняних науковців М. В. Архипової (2009) [2], Л. І. Бондаренко (2013) [3], М. С. Головань (2012) [4], С. У. Гончаренко (2008) [5], С. О. Сисоєвої (2013) [6] та ін., зарубіжних учених Denise Jackson (Австралія, 2013), Catherine Pickering та Jason Byrne (Австралія, 2014) [7], Joan Josep Carvajal (Іспанія, 2017) [8], Lynn McAlpine та Cheryl Amundsen (Канада, 2017) [9], Durette Barthélémy, Fournier Marina, Lafon Matthieu (Франція, 2014) [10] та ін.

Проблемі формування інформаційної (інформаційно-комунікаційної, цифрової, інформаційно-цифрової) компетентності особистості присвячені роботи вітчизняних науковців С. О. Гунько, М. І. Жалдака, Н. В. Морзе, О. М. Спіріна, О. М. Снігура, Ю. В. Триуса, О.І. Шиман та ін.

Використання відкритих електронних систем як підтримки наукової і науковопедагогічної діяльності розглядається у роботах таких учених як В. М. Биков, В. Н. Бурков, А. А. Білошицький, О. Р. Гарасим, С. М. Іванова, Л. Й. Костенко, А. В. Кільченко, Л. А. Лупаренко, Д. О Тарасов, О. М. Спірін, А. В. Яцишин, зарубіжні науковці J. Priem, P. Groth; D. Taraborelli (США, 2012); Robert Light; Polley E David; Katy Borner (США, 2013); P. Suber (США, 2014), Harinarayana N.S. (Індія, 2015) та ін.

В інформаційному суспільстві $€$ затребуваними та активно реалізуються освітні програми та проекти з використання електронних науково-освітніх систем [11]. Разом 3 тим зауважимо, що їх використання для розвитку інформаційно-дослідницької компетентності наукових та науково-педагогічних працівників недостатньо відображено у методичних розробках, навчальних програмах.

Метою статті $є$ уточнення поняття інформаційно-дослідницької компетентності наукових та науково-педагогічних працівників та визначення впливу використання відкритих електронних науково-освітніх систем на її розвиток.

\section{2. ТЕОРЕТИЧНІ ОСНОВИ ДОСЛІДЖЕННЯ}

У статті використано такі методи дослідження: аналіз педагогічних, наукових та методичних джерел - для з'ясування стану розробленості проблеми, визначення й уточнення поняттєво-категоріального апарату дослідження; аналіз та узагальнення зарубіжного та вітчизняного досвіду використання відкритих електронних науковоосвітніх систем у галузі освіти відповідно до принципів відкритої науки. Дослідження проведено у рамках НДР «Методика використання відкритих електронних науково- 
освітніх систем для розвитку інформаційно-дослідницької компетентності наукових і науково-педагогічних працівників» ДР № 0118U003159.

\section{3. РЕЗУЛЬТАТИ ДОСЛІДЖЕННЯ}

Поняття інформаційно-дослідницька компетентність наукових та науковопедагогічних працівників, перш за все, пов'язане з їхніми знаннями, вміннями та навичками, тобто здатністю здійснювати наукову діяльність, що визначається відповідно до основних нормативних документів, які регулюють форми неперервної освіти особистості (післядипломна педагогічна освіта, освіта впродовж життя, неперервна освіта та ін.), а саме: Законом України «Про вищу освіту», «Про наукову і науково-технічну діяльність» [12], Положенням про підвищення кваліфікації та стажування педагогічних і науково-педагогічних працівників вищих закладів освіти [13] та ін.

У Законі «Про наукову і науково-технічну діяльність» зазначається, що наукові та науково-педагогічні працівники мають проводити наукову діяльність, що охоплює наукові дослідження та (або) науково-технічні (експериментальні) розробки відповідно до укладених договорів (контрактів), та характеризується як інтелектуальна творча діяльність, спрямована на одержання нових знань та пошук шляхів їх застосування, основними видами якої є фундаментальні та прикладні наукові дослідження [12]. При цьому, як прикладні так і фундаментальні наукові дослідження базуються на теоретичних та експериментальних наукових дослідженнях, спрямованих на одержання i використання нових знань для створення нових або вдосконалення існуючих матеріалів, продуктів, пристроїв, методів, систем, технологій, висування конкретних пропозиції щодо виконання актуальних науково-технічних та суспільних завдань [12].

Вітчизняні науковці (Л. І. Бондаренко [3], М. С. Головань [4], С. У. Гончаренко [5], С. О. Сисоєва [6] та ін.) акцентують увагу на тому, що науково-дослідна діяльність спрямована на одержання суспільно значущих нових знань про певні об'єкти, процеси або явища і має у своєму процесі такі етапи: планування (проектування) дослідження, що передбачає вміння, навички та здатності виявляти та формулювати проблеми, визначати об'єкт, предмет, мету, гіпотезу, основні поняття дослідження; застосування методів до об'єкта дослідження 3 метою отримання потрібних результатів, що передбачає вміння підбирати та використовувати методи дослідження відповідно до гіпотез, створення масивів емпіричних даних, опрацювання наукових джерел та ін.; формулювання та інтерпретація результатів дослідження, що передбачає вибір i використання спеціальних методів дослідження, розвинуте логічне мислення, творчі здібності і здатності (інтуїція, здатність до інсайту та відкриття, продуктивне мислення та ін.), створення, передавання та впровадження проміжних і остаточних результатів дослідження у практичну та професійну діяльність.

М. В. Архипова визначає «дослідницьку компетентність» згідно з вимогами до професійної компетентності педагога як характеристику особистості педагога, що вказує на володіння вміннями і засобами дослідницької діяльності на рівні технології 3 метою пошуку знань для професійної діяльності, вирішення освітніх проблем та побудови освітнього процесу [2]. Вчена виокремлює такі основні компоненти цієї компетентності як планування, організацію та здійснення пошуково-перетворювальної діяльності, об'єктом якої виступають психолого-педагогічна і галузева складові.

Отже, дослідницька компетентність наукових та науково-педагогічних працівників - це здатність особистості здійснювати науково-дослідну діяльність для одержання суспільно значущих нових знань та застосувати їх на практиці.

Слід відмітити, що вчені [2]-[6] розглядають інформаційно-дослідницьку 
компетентність як один із складників дослідницької компетентності.

Наприклад, С. О. Сисоєва та Т. С. Кристопчук у структурі дослідницької компетентності викладача вищого закладу освіти виокремлюють такі компоненти: мотиваційно-ціннісний; когнітивний; процесуально-діяльнісний; інформаційнокомунікаційний; комунікативний; особистісно-творчий; професійно-рефлексивний [6]. Інформаційно-комунікаційний компонент вони пояснюють як володіння особистістю методами збирання даних відповідно до гіпотез, створення масивів емпіричних даних, опрацювання різноманітних інформаційних джерел та ін. Володіння дослідниками на достатньому рівні цим компонентом дослідницької компетентності передбачає вміння користуватися інформаційними джерелами (навчальною літературою, словниками, довідниками, каталогами, монографіями, періодичними виданнями та ін.), володіння методами роботи 3 науковою літературою, технологією складання бібліографічного списку; вміння оформлювати літературу; здатність працювати 3 інформацією (збір, опрацювання, аналіз, оцінювання повноти інформації) 3 використанням сучасних інформаційно-комунікативних технологій (ІКТ); спроможність до поширення наукових знань як в академічному, так і суспільному середовищах.

Catherine Pickering та Jason Byrne [7], Denise Jackson [14], Joan Josep Carvajal [8], Lynn McAlpine та Cheryl Amundsen [9] та ін. розглядають дослідницьку компетентність згідно з вимогами до захисту дисертаційних досліджень докторів філософії (PhD) та докторів наук (DSc).

Lynn McAlpine, Cheryl Amundsen [9] зазначають, що дослідницька компетентність вчених має включати три основних компоненти: знання, дослідження, проведення навчання (викладання). Компонент «знання» передбачає, що науковець повинен вміти виокремлювати факти, розширювати та уточнювати поняття, визначати основні питання дослідження та надавати на них аргументовані відповіді. Компонент «дослідження» означає, що вчений має здійснювати пошук схем і моделей об'єктів дослідження, аналізувати та пояснювати їх, створювати оновлені або нові схеми і моделі об'єктів дослідження на базі аналізу теоретико-методичних досліджень із наукової проблеми. Компонент «проведення навчання (викладання)» передбачає, що вчений має вміти передавати свої знання іншим, вчити їх креативно мислити, організовувати групове та колективне навчання студентів та ін.

Durette Barthélémy, Fournier Marina, Lafon Matthieu [10] виокремлюють шість компонентів компетентності дослідника:

- знання та спеціалізовані технічні навички (англ. Knowledge and specialized technical skills), що включають в себе посилання на конкретні галузі знань (наприклад, біотехнологію, квантову фізику, обробку сигналів та ін.) та спеціальні методи і ноу-хау, що мають відношення до конкретного контексту докторантури;

- компетентності, що можуть бути формалізовані (англ. Transferable competencies that can be formalized), тобто розвиватися у межах спеціальних навчальних курсах, а саме: навички спілкування, навички управління проектами, навички роботи з інформаційними технологіями, мовні навички, комерційні навички, а також знання професійного середовища (академічного або промислового), управління інноваціями (включаючи наукові спостереження та оцінку) та адміністративного управління;

- компетентності, що не можуть бути формалізовані (англ. Transferable competencies that cannot be formalized), а саме: інтелектуальні можливості, здатність вирішувати складні проблеми (включаючи формулювання проблем та вирішення проблем), здатність до співпраці (внутрішньо або зовнішньо), лідерство, інноваційна спроможність, широке бачення (включаючи широке 
загальне знання або можливість очікувати), здатність ставити під сумнів ідеї й припущення та ін.

- готовність (англ. Dispositions), компонент, що доповнює попередні компетентності особистості, наприклад, готовність до творчості, креативності, управління проектами та ін.

- поведінкові компетентності (англ. Behaviors), наприклад, вони варіюються від управління стресом до наполегливості, серед іншого: цікавість, слухання інших, стійкість, динамічність, терпіння та чесність (авторами було виявлено 32 різні поведінкові компетентності);

- мета-компетентності, що охоплюють здатність до навчання та адаптації.

Крім цього, вчені Catherine Pickering, Jason Byrne [7], Denise Jackson [14] особливо відзначають вміння дослідників писати наукові статті. Вони стверджують, що саме наукові статті свідчать про рівень дослідницької компетентності науковця, допомагають їм оприлюднювати свої наукові результати та отримувати зворотній зв'язок від рецензентів, керівників та інших науковців про їх стиль написання, методи, аналіз результатів та ін., що значно впливає на якість їхніх подальших досліджень.

3 огляду на це, важливого значення набуває проблема розвитку інформаційнодослідницької компетентності науковців для підтримки проведення досліджень Для уточнення терміну інформаційно-дослідницької компетентності ми враховуємо Свропейську рамку цифрової компетентності для громадян (DigComp 2.1), в якій зазначається, що ця компетентність є здатністю особистості застосовувати IКТ у житті, навчанні та праці, постійно оновлювати эï впродовж життя [15]. Вона охоплює такі 5 сфер: інформаційну грамотність та уміння працювати 3 даними, комунікацію та співробітництво, створення цифрового контенту, безпеку, рішення проблем. Таким чином інформаційно-дослідницька компетентність має розглядатися як окрема характеристика наукових та науково-педагогічних працівників згідно з особливими вимогами до них, що висуваються відповідно до розвитку інформаційного суспільства, однією з яких є вільне володіння ІКТ для успішної професійної діяльності, особистих потреб та навчання впродовж життя.

Отже, на нашу думку, інформаційно-дослідницька компетентність наукового та науково-педагогічного прачівника - це здатність здійснювати з використанням IКТ пошук, збирання, опрацювання, аналіз та представлення наукових даних відповідно до методології наукового дослідження, комунікацію, співробітництво та навчання інших, вміння використовувати сервіси електронних науково-освітніх систем для інформаційно-аналітичної підтримки науково-педагогічних досліджень, моніторингу та оцінювання наукових результатів, продукування нових суспільно-значущих знань 3 метою впровадження їх у практику освіти та науки.

3 огляду на вищевикладене, для розвитку інформаційно-дослідницької компетентності наукових та науково-педагогічних працівників важливим $\epsilon$ використання відкритих електронних науково-освітніх систем, що безпосередньо пов'язано 3 поняттям «науково-освітні інформаційні мережі». Вчені В. Ю. Биков, О. М. Спірін, М.П.Шишкіна [11] визначають це поняття як автоматизовані інформаційні системи (AIC), що включають дані переважно освітнього і наукового спрямування, забезпечують інформаційну підтримку освіти й науки та технологічно використовують комп'ютерну інформаційно-комунікаційну платформу для транспорту і опрацювання інформаційних об'єктів.

Зарубіжні дослідники Antonio Lafuente (Іспанія, 2015) [16], Cameron Neylon (Велікобританія, 2015) [16] та ін. при визначенні відкритих електронних науковоосвітніх систем виходять із змісту поняття «Відкрита наука», яке охоплює різні практики та інструменти, пов'язані 3 використанням цифрових технологій та 
альтернативних інструментів інтелектуальної власності. Відкрита наука - це дані досліджень, лабораторні звіти та ін., що є вільно доступними, відповідно до умов, що дозволяють науковцям повторно використовувати, перерозподіляти та відтворювати дослідження, його основні дані та методи.

Згідно з дослідженнями, які проводилися у межах проекту Європейського Союзу FOSTER (https://www.fosteropenscience.eu), була розроблена таксономія відкритої науки (рис.1).

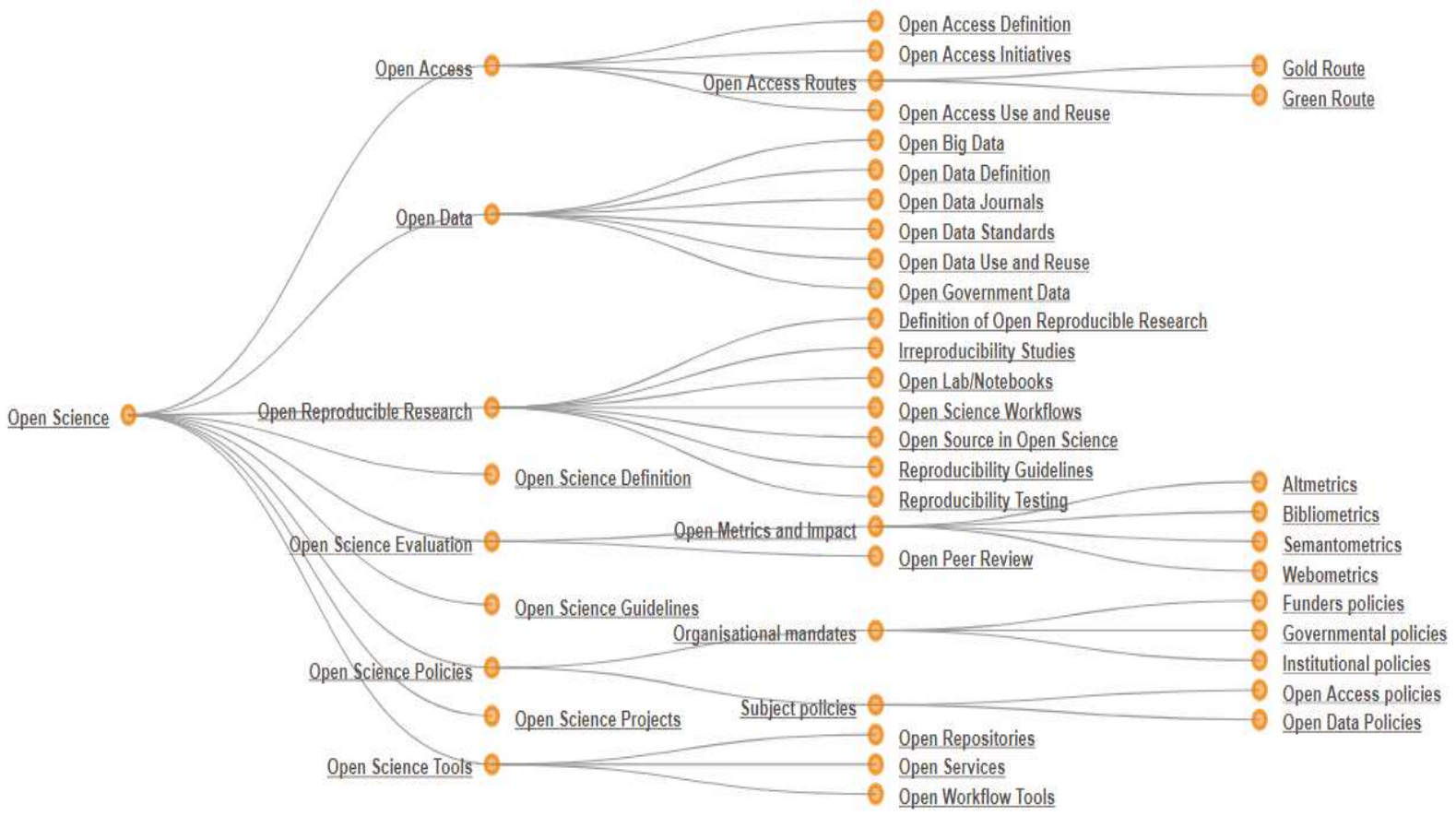

Рис. 1. Таксономія відкритої науки (https://www.fosteropenscience.eu)

На рис. 1 відображена інтелектуальна мапа дефініцій або тем, що включає поняття «відкрита наука», а саме: відкритий доступ (англ. Open Access), відкриту базу даних (англ. Open Data), відкрите репродуктивне дослідження (англ. Open Reproductive Research), відкрите оцінювання наукової діяльності (англ. Open Science Evaluation), відкрита наукова політика (англ. Open Science Policies) та відкриті інструменти для наукових досліджень (англ. Open Science Tools). Кожна з цих тем включає багато інших підтем, що відображають спектр проблем, з якими може стикатися дослідник у межах відкритої науки.

Як показано на рис. 1, відкрита наука складається з компонентів, реалізація яких відбувається через відкриті електронні науково-освітні системи. Розглянемо ці компоненти докладніше та визначимо їх можливий вплив на розвиток інформаційнодослідницької компетентності наукових та науково-педагогічних працівників.

Поняття відкритий доступ стосується результатів досліджень, які вільно поширюються в Інтернеті, зокрема 3 додаванням ліцензії Creative Commons для підтримки прав автора [17]. Відкритий доступ може застосовуватися до всіх видів опублікованих досліджень, включаючи рецензовані та нерецензовані статті у журналах та збірниках конференцій, тези, розділи книг, монографій та ін. Це поняття включає:

- відкриті наукові напрямки (англ. Open Science Routes), що реалізуються двома шляхами - «золотим» (англ. Gold Road), який пояснюється як вільний доступ до всіх матеріалів безпосередньо у момент публікації, та «зеленим» (англ. Green Road), який пояснюється як депонування та самоархівування науковцями 
власних праць у відкритих електронних архівах (репозитаріях) відповідно до стандартів Open Archives Initiative Protocol for Metadate Harvesting (OAI-PMH);

- відкриті наукові поняття (англ. Open Science Definition), під якими маються на увазі відповідальні дослідження та інновації, інтерактивні процеси, за допомогою яких суспільні суб'єкти та новатори взаємодіють один $з$ одним 3 метою впровадження науково-технічних досягнень у суспільстві;

- відкриті наукові ініціативи (англ. Open Science Initiatives), які охоплюють проведення та провадження наукових проектів у вільному доступі, участь науковців у конкурсах на отримання грантів та ін.

Відкритий доступ до результатів наукових досліджень забезпечується завдяки створенню наукових електронних бібліотек на базі, наприклад, таких платформ як EPrints i DSpace; відкритих електронних конференцій, що розміщуються в мережі за допомогою відкритих систем (англ. System Open Conference, OCS) та ін. Отже, можна припустити, що відкритий доступ сприяє розвитку інформаційно-дослідницької компетентності наукових та науково-педагогічних працівників у галузі вирішення науково-дослідних проблем, а саме: за допомогою ІКТ здійснення пошуку електронних освітніх та наукових матеріалів; оприлюднення особистих наукових результатів, пошук однодумців щодо наукових ідей, інновацій та їх впровадження.

Відкрита база даних за таксономією відкритої освіти (рис. 1) визначається як вільно доступні набори даних, що важливі для наукових досліджень, наприклад, документи, патенти, гранти, клінічні випробування [18], та включає в себе відкриту масштабну базу даних (англ. Open Big Data), відкриту базу даних дефініції (англ. Open Data Definition), відкриту базу даних наукових журналів (англ. Open Data Journals), відкриту базу даних стандартів (англ. Open Data Standards), відкриту базу даних для використання та повторного використання даних (англ. Open Data Use and Reuse), відкриті урядові дані (англ. Open Gaverment Data). Відкриті дані - це ідея про те, що деякі дані повинні бути вільно доступними кожному, щоб вони використовувались за власним бажанням дослідника, без обмежень авторськими правами, патентами та іншими механізмами контролю [19]. Ці дані, зазвичай, включають наступні матеріали: відкриті джерела та посилання, відкрите обладнання, відкритий контент, відкриту освіту, відкриті освітні ресурси, відкрите управління, відкриті знання, відкритий доступ, відкриту науку та відкриті ін. Веб-ресурси. Філософія відкритих даних набуває популярності відповідно до ініціатив уряду відкритих даних, таких як Data.gov, Data.gov.uk та Data.gov.in, хмарних технологій, таких як, наприклад, Google Scholar, You Tube та ін. Відкриті бази даних, на нашу думку, можуть сприяти розвитку вмінь $\mathrm{i}$ навичок наукових та науково-педагогічних працівників щодо пошуку необхідних відомостей для їхніх досліджень, користування різними сервісами, зокрема хмарними, для сумісної роботи над дослідженням із своїми колегами, обговорення статей та інших наукових продуктів.

Відкрите репродуктивне дослідження - це дані та програмне забезпечення, необхідне для відтворення наукових результатів на практиці та для подальших досліджень, що пов'язані 3 попередніми. Відкриті репродуктивні дослідження охоплюють такі поняття як визначення відкритих репродуктивних досліджень (англ. Definition of Open Reproducible Research), визначення відкритих нерепродуктивних досліджень (англ. Irreproducibility Studies), відкриті лабораторні дослідження (англ. Open Lab/Notebooks), відкриті наукові робочі процеси (англ. Open Science Workflows), відкритий вихідний код у відкритих науках (англ. Open Source in Open Science), керівні принципи відтворюваності наукових досліджень (англ. Reproduciblity Guidelines), тестування та моніторинг результатів наукових досліджень (англ. Reproduciblity Testing) [16]. 
Відкрите оцінювання наукової діяльності є альтернативою традиційним системам оцінювання показників результатів наукової діяльності, а саме, новий спосіб оцінювання впливу наукових результатів, що включає наступні рішення: відкрите оцінювання вченими наукових досліджень один одного (англ. Open peer review); відкриті показники та вплив наукових досліджень на розвиток науки (англ. Open Metrics and Impact), що охоплює:

- альтметричні методи оцінювання (англ. Altmetrics) - проект, що направлений на створення метрики наукової статті зі статей, розміщених в мережі Інтернет, наприклад, сайтів соціальних мереж, газет та інших джерел [20]; Altmetrics - це вивчення та проведення наукових заходів у онлайн-середовищах, наприклад, згадування наукових робіт учених у Facebook, Twitter, ïx експорт у такі системи як Mendeley або Zotero, коментарі в блогах та ін.;

- бібліометричні методи оцінювання (англ. Bibliometrics) - цитати і контентаналіз, що використані в Open Science, наприклад, популярним бібліометричним програмним забезпеченням/інструментами $\epsilon$ : BibExcel, CiteSpace, Eigenfactor Score, HistCite, Pajek, Publish or Perish, Scholarometer, Scholar h-index Caculator та ін. [21];

- семантометричні методи (англ. Semantometrics) на відміну від існуючих бібліометричних, вебометричних, альтметметричних та інших методів, не засновані на вимірюванні кількості взаємодій у науковій мережі, при цьому методі використовують переважно повні тексти рукописів для оцінки вартості публікації у науковому просторі [22], зокрема одними з інструментів для здійснення семантометричного методу може виступати системи антиплагіату Advego Plagiatus, Etxt Antiplagiat, Unichek, Double Content Finder, Praide Unique, Content Analyser II, Viper Anti-Plagiarism та ін.;

- вебометрічні методи (англ. Webometrics) вивчення кількісних аспектів побудови та використання інформаційних ресурсів, структур та технологій за допомогою Web-орієнтованих бібліометричних та інформометричних підходах [23].

Вищевикладені методи оцінювання наукової діяльності вчені об'єднують у загальний підхід - інформетрію (англ. informetrics), що визначається ними як напрям метричного дослідження, пов'язаного 3 інформатикою, зокрема бібліометрією (бібліографії, бібліотеки та ін.), наукометрією (наукова політика, аналіз цитування, оцінка дослідження та ін.), вебометрією (метрики мережі, інтернету або інших соціальних мереж, як мережі цитування або співпраці) [24]. В Свропі активно реалізуються освітні програми 3 питань використання відкритих науково-освітніх систем, підготовка характеризується варіативністю освітніх форм і їх змісту. Навчання організовано на різних рівнях системи професійної освіти (за винятком бакалаврату), додаткової освіти та самоосвіти. Навчальні курси з інформетрії $є$ в програмах навчання магістрів та підготовки докторантів в різних університетах світу. Як правило, це курси за вибором (англ. elective course). Наприклад, Каліфорнійський університет в ЛосАнджелесі (англ. University of California, Los Angeles, USA: http://www.ucla.edu/) пропонує здобувачам ступеня магістра бібліотечної та інформаційної науки (англ. Master of Library and Information Science, MLIS) або ступеня доктора філософіï (PhD) курс «Наукова комунікація і бібліометрія» (англ. Scholarly communication and bibliometrics course), який позиціонується як введення в методологію і методи бібліометричних досліджень (http://polaris.gseis.ucla.edu/ jfurner/classes/is208syl.pdf).

Курс «Вимір науки» (англ. Graduate course on Measuring Science), організований дослідним центром CWTS (англ. Centre for Science and Technology Studies, Leiden 
University, Leiden, Netherlands: https://www.cwts.nl/), представляє нові розробки щодо кількісних досліджень науки і техніки.

В Школі бібліотечної та інформаційної науки в Данії (англ. Royal School of Library and Information Science, RSLIS, Copenhagen, Denmark) викладається трирічна програма «Доктор філософії з бібліометрії і оцінювання досліджень» (англ. $\mathrm{PhD}$ position in Bibliometrics and Research Evaluation: http://listar.hi.is/pipermail/ norslis/2012January/000246.html).

Крім університетів i коледжів, інформетрію пропонують вивчати та використовувати у межах міжнародних проектів, семінарів, тренінгів та ін. Так, серед найбільш популярних міжнародних проектів, в яких застосовується учасниками цей напрям, можна виокремити такі:

- Міжнародний проект «Свропейська літня школа 3 наукометрії» (European Summer School for Scientometrics, ESSS), який стартував у 2010 році. Його організатори - університет Відня (University of Vienna, Austria), університет ім. В. Гумбольдта (Humboldt University of Berlin, Germany), Католицький університет в м. Левен (Katholieke Universiteit Leuven, Belgium), а також Інститут дослідження інформації та контролю якості (Institute for Research Information and Quality Assurance, Germany) (http://www.scientometricsschool.eu).

- Проект «Скандинавський семінар з бібліометрії та дослідницької політики» (Nordic Workshop on Bibliometrics and Policy Research). Семінари проводяться щорічно з 1996 року. Основна мета проекту полягає у представленні нових бібліометричних досліджень в скандинавських країнах.

Використання засобів та методів відкритого оцінювання наукової діяльності надають нові можливості щодо аналізу значення електронних освітніх ресурсів для сучасного суспільства, публікаційної активності науковців, рівня ефективності їх наукової діяльності; дозволяють фіксувати рівень актуальності науково-дослідних робіт, тем, публікацій та ін. наукової продукції через відстеження значень показників, наприклад, електронних бібліометричних систем, що застосовуються науководослідними установами [15].

Відкрита наукова політика забезпечується через провадження відкритих наукових конкурсів, результатом яких $є$ отримання науковцями та науковими установами грантів, сертифікатів та ін. За таксономією відкритої освіти (рис.1) відкрита наукова політика включає:

- організаційні мандати (англ. Organisational mandates), що пояснюється як письмові схвалення організацій з конкретних питань, вони включають політику спонсорів (англ. Funders policies), державну політику (англ. Governmental policies), інституційну політику (англ. Institutional policies);

- предмети політики (англ. Subject policies), що включають відкритий доступ до політики (англ. Open Access policies) та відкриту базу даних щодо політики відкритої науки (англ. Open Data policies).

Відкриті наукові проекти (англ. Open Science Projects) - це глобальні міжнародні проекти, метою яких, перш за все, $є$ [23] підвищення якості освіти та науки у світовому інформаційному просторі, наприклад, Горизонт 2020 (англ. Horizon 2020 (https://ec.europa.eu/research/participants/portal/desktop/en/home.html), «Технологія наставництва для підвищення якості педагогіки» (англ. MENtoring TechnologyEnhanced Pedagogy, MENTEP (http://mentep.eun.org/home) та ін.

Відкриті інструменти для наукових досліджень (англ. Open Science Tools), a caме:

- відкриті репозитарії (англ. Open Repositories), що є відкритими архівами, які містять наукову літературу та роблять їх вміст вільними для всіх, хто має в них необхідність; 
- відкриті сервіси (англ. Open Services) - заходи та послуги, що пропонуються організаціями та установами безкоштовно;

- відкриті інструменти для робочого процесу (англ. Open Workflow Tools) апарати та послуги, що сприяють проведенню відкритих наукових проектів.

Ми погоджуємося 3 таксономією, зробленою у межах проекту Європейського Союзу FOSTER, та відмічаємо, що всі поняття, які виокремлені для провадження відкритої науки, зокрема відкритих електронних науково-освітніх систем, пов'язані між собою. Так, наприклад, поняття відкритий доступ може бути пов'язане з поняттями, які входять до відкритих баз даних, відкритого оцінювання наукової діяльності та ін., оскільки для забезпечення відкритого доступу, зокрема до баз даних, можуть використовуватися однакові інструменти (наприклад, Google Analitics, Google Apps for Education, SharePoint та ін.), політика (наприклад, документи, що розміщуються на сайтах міжнародних проектів, міністерств освіти країн та ін.), критерії оцінювання (наприклад, критерії оцінювання цитованості статті науковця) та ін.

3 огляду на вищезазначене, узагальнимо та визначимо результат використання відкритих науково-освітніх систем для розвитку інформаційно-дослідницької компетентності наукових та науково-педагогічних працівників (таблиця 1).

Табличя 1.

Використання відкритих науково-освітніх систем для розвитку інформаційнодослідницької компетентності наукових та науково-педагогічних працівників

\begin{tabular}{|c|c|c|}
\hline $\begin{array}{c}\text { Приклади відкритих } \\
\text { електронних науково- } \\
\text { освітніх систем }\end{array}$ & $\begin{array}{c}\text { Теми таксономії } \\
\text { відкритої науки за } \\
\text { проектом FOSTER }\end{array}$ & $\begin{array}{c}\text { Результат використання } \\
\text { відкритих науково-освітніх систем } \\
\text { для розвитку інформаційно- } \\
\text { дослідницької компетентності } \\
\text { наукових та науково-педагогічних } \\
\text { працівників } \\
\end{array}$ \\
\hline $\begin{array}{l}\text { Платформи EPrints i DSpace } \\
\text { для створення електронних } \\
\text { бібліотек, відкриті електронні } \\
\text { конференції OCS та ін. }\end{array}$ & $\begin{array}{l}\text { Відкритий доступ (англ. } \\
\text { Open Access) }\end{array}$ & $\begin{array}{l}\text { Шляхи вирішення проблем } \\
\text { проведення наукових досліджень, а } \\
\text { саме: за допомогою ІКТ пошук } \\
\text { електронних освітніх та наукових } \\
\text { матеріалів; оприлюднення } \\
\text { особистих наукових результатів, } \\
\text { пошук колег, співавторів, спільноти } \\
\text { щодо наукових ідей, інновацій та їх } \\
\text { впровадження }\end{array}$ \\
\hline $\begin{array}{l}\text { Google Scholar, Google Apps for } \\
\text { Education, Google Forms та ін. }\end{array}$ & $\begin{array}{l}\text { Відкрита база даних } \\
\text { (англ. Open Data) }\end{array}$ & $\begin{array}{l}\text { Розвинені вміння та навички } \\
\text { наукових і науково-педагогічних } \\
\text { працівників, що дозволяють } \\
\text { знаходити необхідні відомості, } \\
\text { користування різними сервісами, } \\
\text { зокрема хмарними науково- } \\
\text { освітніми, для спільної роботи над } \\
\text { дослідженням разом з колегами, } \\
\text { обговорення публікацій та інших } \\
\text { наукових продуктів }\end{array}$ \\
\hline $\begin{array}{l}\text { Системи управління науковою } \\
\text { бібліографією, зокрема } \\
\text { Thomson Reuters Web of } \\
\text { Science EndNote Web, Zotero, } \\
\text { BibMe, Citation Machine та ін. }\end{array}$ & $\begin{array}{l}\text { Відкрите репродуктивне } \\
\text { дослідження (англ. Open } \\
\text { Reproductive Research) }\end{array}$ & $\begin{array}{l}\text { Відповідальне ставлення до } \\
\text { особистих досліджень та досліджень } \\
\text { інших науковців, що полягає у } \\
\text { академічній доброчесності, вмінні } \\
\text { здійснювати перевірку } \\
\text { автентичності наукових текстів та } \\
\text { навчати цьому інших }\end{array}$ \\
\hline $\begin{array}{l}\text { Facebook, You Tube; } \\
\text { Academia.edu, ResearchGate, } \\
\text { Scientific Social Community, }\end{array}$ & $\begin{array}{l}\text { Відкрите оцінювання } \\
\text { наукової діяльності (англ. } \\
\text { Open Science Evaluation) }\end{array}$ & $\begin{array}{l}\text { Комунікаційні навички та вміння } \\
\text { застосовувати їх для оцінювання та } \\
\text { самооцінювання наукових }\end{array}$ \\
\hline
\end{tabular}




\begin{tabular}{|c|c|c|}
\hline $\begin{array}{l}\text { Ukrainian Scientists Worldwide; } \\
\text { Advego Plagiatus, Etxt } \\
\text { Antiplagiat, Unichek, Double } \\
\text { Content Finder та ін. }\end{array}$ & & $\begin{array}{l}\text { досліджень, презентування наукових } \\
\text { результатів }\end{array}$ \\
\hline $\begin{array}{l}\text { Facebook, Twitter; } \\
\text { сайти Міністерств освіти } \\
\text { різних країн, міжнародних } \\
\text { проектів та ін. }\end{array}$ & $\begin{array}{l}\text { Відкрита наукова } \\
\text { політика (англ. Open } \\
\text { Science Policies) }\end{array}$ & $\begin{array}{l}\text { Відповідальне ставлення до } \\
\text { реформування у галузі освіти і } \\
\text { науки, професійних обов' язків, } \\
\text { навчання впродовж життя }\end{array}$ \\
\hline $\begin{array}{l}\text { Платформи Horizon } 2020 \\
\text { (https://ec.europa.eu/research/parti } \\
\text { cipants/portal/desktop/en/home.ht } \\
\text { ml), MENTEP } \\
\text { (http://mentep.eun.org/home) та } \\
\text { iн. }\end{array}$ & $\begin{array}{l}\text { Відкриті наукові проекти } \\
\text { (англ. Open Science } \\
\text { Projects) }\end{array}$ & $\begin{array}{l}\text { Критичне мислення, вміння } \\
\text { здійснювати наукову діяльність у } \\
\text { межах наукових проектів і конкурсів }\end{array}$ \\
\hline $\begin{array}{l}\text { Інші засоби та сервіси, що } \\
\text { сприяють підтримці } \\
\text { проведення науково-дослідної } \\
\text { роботи (відкриті репозитарії, } \\
\text { відкриті сервіси, відкриті } \\
\text { інструменти для робочого } \\
\text { процесу та ін.) }\end{array}$ & $\begin{array}{l}\text { Відкриті інструменти для } \\
\text { наукових досліджень } \\
\text { (англ. Open Science Tools) }\end{array}$ & $\begin{array}{l}\text { Вміння здійснювати пошук та аналіз } \\
\text { даних, взаємодіяти через цифрові } \\
\text { технології із науковою спільнотою, } \\
\text { управляти цифровою } \\
\text { ідентифікацією, розробляти } \\
\text { цифровий контент, креативно } \\
\text { використовувати ІКТ у професійній } \\
\text { діяльності }\end{array}$ \\
\hline
\end{tabular}

Відповідно до таблиці 1 визначені основні аспекти, приклади засобів та теми відкритої науки, що можуть сприяти розвитку інформаційно-дослідницької компетентності наукових та науково-педагогічних працівників особливо у таких напрямах як розвиток критичного мислення науковців, підбір он-лайн інструментів, за допомогою яких можна знайти шляхи розв'язання проблем, що виникають при здійсненні науково-дослідної роботи.

\section{4. ВИСНОВКИ ТА ПЕРСПЕКТИВИ ПОДАЛЬШИХ ДОСЛІДЖЕНЬ}

Отже, відповідно до аналізу наукової літератури, нами уточнено поняття «інформаційно-дослідницька компетентність наукових та науково-педагогічних працівників», а саме, - це здатність здійснювати з використанням IКТ пошук, збирання, опрацювання, аналіз та представлення наукових даних відповідно до методології наукового дослідження, комунікацію, співробітництво та навчання інших, вміння використовувати сервіси електронних науково-освітніх систем для інформаційноаналітичної підтримки науково-педагогічних досліджень, моніторингу та оцінювання наукових результатів, продукування нових суспільно-значущих знань 3 метою впровадження їх у практику освіти та науки.

Важливим $\epsilon$ виокремлення відкритих електронних науково-освітніх систем використання яких має вплив на розвиток інформаційно-дослідницької компетентності наукових та науково-педагогічних працівників. Серед таких систем варто виокремити платформи для створення електронних бібліотек, відкритих конференцій, хмарні науково-освітні сервіси, рейтингові вітчизняні й міжнародні системи, інформаційноаналітичні портали, системи та каталоги, сервіси для управління науковою бібліографією, моніторингу та оцінювання науково-дослідної діяльності наукових та науково-педагогічних працівників та ін.

Перспективами дослідження $\epsilon$ розробка методики використання відкритих електронних науково-освітніх систем для розвитку інформаційно-дослідницької компетентності наукових і науково-педагогічних працівників. 


\section{СПИСОК ВИКОРИСТАНИХ ДЖЕРЕЛ}

[1]. С. М. Іванова, "Використання міжнародної наукометричної системи Web of Science для наукових i педагогічних досліджень", Наукові записки ЦДПУ ім. В. Винниченка. Серія: Педагогічні науки, Випуск 169, с. 68-72, 2018.

[2]. М. В. Архипова, "Дослідницька компетентність майбутніх інженерів-педагогів", $V$ міжн. наук.практ. конф. Професійне становлення особистості: проблеми $і$ перспективи, Хмельницький, 2009, c. $144-148$.

[3]. Л. І. Бондаренко, Розвиток досліднищької компетентності майбутніх викладачів вищих навчальних закладів: Метод. рек. для виклад. вищих навч. закл., аспірантів, магістрантів. Луганськ: Вид-во ДЗ "ЛНУ ім. Тараса Шевченка", 2013, с. 56.

[4]. М. С. Головань, "Модель формування дослідницької компетентності майбутніх фахівців у процесі професійної підготовки", Педагогічні науки: теорія, історія, інноваційні технології, № 5 (23), c. $196-205,2012$.

[5]. С. У. Гончаренко, Педагогічні дослідження. Методологічні поради молодим науковиям: Посібник. Київ-Вінниця: ДОВ «Вінниця», 2008, с. 278.

[6]. С. О. Сисоєва, та Т. Є. Кристопчук, Методологія науково-педагогічних досліджень: Підручник. Рівне: Волинські обереги, 2013, с. 360.

[7]. C. Pickering, and J. Byrne, "The benefits of publishing systematic quantitative literature reviews for PhD candidates and other early-career researchers", Higher Education Research \& Development, vol. 33, No. 3, pp. 534-548, 2014.

[8]. M Reguero, J. Carvajal, M. García, and M. Valverde, Good Practices in Doctoral Supervision: Reflections from the Tarragona Think Tank, Publicacions Universitat Rovira i Virgili, 2017.

[9]. L. McAlpine, Ch. Amundsen, Identity-Trajectories of Early Career Researchers: Unpacking the PostPhD Experience, Springer, 2017.

[10]. B. Durette, M. Fournier, and M. Lafon, "The core competencies of PhDs", Studies in Higher Education, vol. 41 (8), pp. 1355-1370, doi/full/10.1080/03075079.2014.968540, 2014.

[11]. В. Ю. Биков, О. М. Спірін, та М. П. Шишкіна, "Корпоративні інформаційні системи підтримування науково-освітньої діяльності на базі хмаро орієнтованих сервісів", 3б. наук. пр.: Проблеми та перспективи формування національної гуманітарно-технічної еліти, Вип. 43 (47), ч. 2, с. 178-206, 2015.

[12]. Верховна Рада України (2015, Лист. 26). Закон України № 848-VIII, Про наукову і науковотехнічну діяльність (із зм.; у ред. від 01.01.2017, підстава № 1774-19, № 1801-19). [Електронний peсурс]. Режим доступу: http://zakon3.rada.gov.ua/laws/show/848-19.

[13]. Верховна Рада України (2013, Січ. 24). Положення про підвищення кваліфікації та стажування педагогічних і науково-педагогічних працівників вищих навчальних закладів № 48, затверджено наказом МОНмолодьспорту України. [Електронний ресурс]. Режим доступу: http://zakon3.rada.gov.ua/laws/show/z0488-13.

[14]. D. Jackson, "Completing a PhD by publication: a review of Australian policy and implications for practice", ECU Publications. 2013. [Електронний ресурс]. Режим доступу: http://ro.ecu.edu.au/cgi/viewcontent.cgi?article=1014\&context=ecuworks. Дата звернення: 25 Жовтня 2018.

[15]. S. Carretero, R. Vuorikari, and Y. Punie, DigComp 2.1: The Digital Competence Framework for Citizens with eight proficiency levels and examples of use. Publications Office of the European Union EUR 28558 $\mathrm{EN},-2017$. [Електронний ресурс]. Режим доступу: http://publications.jrc.ec.europa.eu/repository/bitstream/JRC106281/web-digcomp2.1pdf__ (online).pdf. Дата звернення: 28 Жовтня 2018.

[16]. S. Albagli, M. L. Maciel, and A. H. Abdo, Open Science, open issues. Rio de Janeiro: Unirio, Brasília: IBICT, 2015. [Електроннй ресурс]. Режим доступу: https://www.academia.edu/15431919/Open_Science_Open_Issues. Дата звернення: 30 Жовтня 2018.

[17]. P. Suber, "Open Access Overview". Retrieved Nov. 29, 2014. [Електронний ресурс]. Режим доступу: https://legacy.earlham.edu/ peters/fos/overview.htm. Дата звернення: 20 Жовтня 2018.

[18]. R. Light, P. E. David, and K. Borner, "Open Data and Open Code for Big Science of Science Studies". RetrievedJuly 2013 [Електронний ресурс]. Режим доступу: https://www.researchgate.net/publication/257199876_Open_Data_and_Open_Code_for_Big_Science_of _Science_Studies. Дата звернення: 12 Жовтня 2018.

[19]. S. R., Auer, C. Bizer, G. Kobilarov, J. Lehmann, R. Cyganiak, and Z. Ives, "DBpedia: A Nucleus for a Web of Open Data". The Semantic Web. Lecture Notes in Computer Science, 4825, pp. 722-735, doi:10.1007/978-3-540-76298-0_52, 2007. 
[20]. J. Priem, P. Groth, and D. Taraborelli, ed. Ch. A. Ouzounis, "The Altmetrics Collection", PLoS ONE. vol. 7 (11): e48753, doi:10.1371/journal.pone.0048753, 2012.

[21]. N. S. Harinarayana, "Data Sources and Software Tools for Bibliometric Studies". [Електронний ресурс]. Режим доступу: https://epgp.inflibnet.ac.in/epgpdata/uploads/epgp_content/library_and_information_science/informetrics _\&_scientometrics/data_sources_and_software_tools_for_bibliometric_studies/et/333_et_m2.pdf. Дата звернення: 12 Жовтня 2018.

[22]. V. Weigert, "Towards Full-Text Based Research Metrics: Exploring Semantometrics". Library \& Scholarly Futures. JISC (Joint Information Systems Committee). Retrieved Aug. 19, 2016. [Електронний pecypc]. Режим доступу: http://repository.jisc.ac.uk/6376/1/Jisc-semantometrics-experiments-reportfinal.pdf. Дата звернення: 12 Жовтня 2018.

[23]. M. Thelwall, Introduction to Webometrics: Quantitative Web Research for the Social Sciences. Morgan \& Claypool, doi.org/10.2200/S00176ED1V01Y200903ICR004, 2009.

[24]. L. Egghe, "Expansion of the field of informetrics: origins and consequences", Information Processing \& Management, vol. 41, № 6, pp. 1311-1316, 2005.

Матеріал надійшов до редакиії 08.11.2018p.

\title{
ПРОБЛЕМА РАЗВИТИЯ ИНФОРМАЦИОННО-ИССЛЕДОВАТЕЛЬСКОЙ КОМПЕТЕНТНОСТИ НАУЧНЫХ И НАУЧНО-ПЕДАГОГИЧЕСКИХ РАБОТНИКОВ С ИСПОЛЬЗОВАНИЕМ ОТКРЫТЫХ ЭЛЕКТРОННЫХ НАУЧНО-ОБРАЗОВАТЕЛЬНЫХ СИСТЕМ
}

\author{
Иванова Светлана Николаевна \\ кандидат педагогических наук \\ Институт информационных технологий и средств обучения НАПН Украины, г. Киев, Украина \\ ORCID ID 0000-0002-3613-9202 \\ iv69svetlana@gmail.com
}

\begin{abstract}
Аннотация. Статья посвящена проблеме развития информационно-исследовательской компетентности научных и научно-педагогических работников с целью содействия процессу повышения качества результатов их работ, созданию и использованию открытых электронных систем для поддержки научной и образовательной теоретикометодологической и практической баз. Уточнено понятие информационноисследовательская компетентность научных и научно-педагогических работников, которая определяется как способность осуществлять с использованием ИКТ поиск, сбор, обработку, анализ и представление научных данных в соответствии с методологией научного исследования, коммуникацию, сотрудничество и обучение других, умение использовать сервисы электронных научно-образовательных систем для информационно-аналитической поддержки научно-педагогических исследований, мониторинга и оценки научных результатов, выработки новых общественно-значимых знаний с целью внедрения их в практику образования и науки. Описан основной зарубежный опыт внедрения учебных программ по информетрии для развития информационно-исследовательской компетентности научных и научно-педагогических работников. Определено влияние открытых электронных научно-образовательных систем на развитие информационноисследовательской компетентности научно-педагогических работников. Выяснено, что важным является выделение открытых электронных научно-образовательных систем, имеющих особое влияние на развитие этой компетентности для обеспечения открытой науки. Среди таких систем важное значение имеют платформы для создания электронных библиотек, открытых электронных конференций, сервисы для управления научной библиографией, мониторинга научно-исследовательской деятельности научных и научнопедагогических работников и др. Определено, что перспективами исследования для развития информационно-исследовательской компетентности научных и научнопедагогических работников является разработка для этого процесса методики использования открытых научно-образовательных систем в соответствии с принципами открытой науки.
\end{abstract}

Ключевые слова: информационно-коммуникационные технологии; открытая наука; открытые электронные научно-образовательные системы; научные и научно- 
педагогические работники; информационно-исследовательская компетентность, информетрия.

\title{
THE PROBLEM OF THE SCIENTIFIC AND PEDAGOGICAL PROFESSIONALS' INFORMATIONAL AND RESEARCH COMPETENCY DEVELOPMENT WITH THE USE OF OPEN ELECTRONIC EDUCATIONAL AND SCIENTIFIC SYSTEMS
}

\section{Svitlana M. Ivanova}

PhD of Pedagogical Sciences, Head of the Department of Open Education and Scientific Information Systems Institute of Information Technologies and Learning Tools of NAES of Ukraine, Kyiv, Ukraine ORCID ID 0000-0002-3613-9202

iv69svetlana@gmail.com

\begin{abstract}
The article is devoted to the development of scientific and pedagogical professionals' information and research competency with the aim to promote the process of improving their work quality results, to create and use open electronic systems for support scientific, educational, theoretical and methodological and practical bases. It can provide modernization of the national education and science in according with world trends. The concept of scientific and pedagogical professionals' information and research competency is defined in, such as the ability to use ICT for search, compile, analyze and present scientific materials according with the methodology of the scientific research, communication, cooperation and training other educators, to use the services of scientific and educational systems for informational and analytical support of scientific and pedagogical researches, monitoring and evaluation scientific results, to product new socially significant knowledge with the aim to promote the implementation its to their research and education practice. The main foreign experience in implementing educational programs of informometry for the scientific and pedagogical professionals' informational and research competency development is described in the article. The open electronic educational and scientific s systems' impact on the development of scientific and pedagogical professionals' information and research competency is determined in. It has been found out, that selection of open electronic scientific and educational systems becomes important for the development of scientific and pedagogical professionals' information and research competency. The platforms for the electronic libraries creation, open electronic conferences, services for the management of scientific bibliography, monitoring of scientific research activities of scientific and scientific and pedagogical workers, etc., are particular importance for the development of scientific and pedagogical professionals' information and research competency. The development of a methodology for the use open scientific and educational systems in accordance with the open science principles is the prospects for research on the development of scientific and pedagogical professionals' information and research competency.
\end{abstract}

Keywords: information and communication technologies; open science; open electronic educational and scientific systems; scientific and pedagogical professionals; information and research competency; informetrics.

\section{REFERENCES (TRANSLATED AND TRANSLITERATED)}

[1]. S. M. Ivanova, "Use of the international science-computer system of Web of Science for scientific and pedagogical researches", Naukovi zapysky TsDPU im. V. Vynnychenka. Seriia: Pedahohichni nauky, Vypusk 169, s. 68-72, 2018 (in Ukrainian).

[2]. M. V. Arkhypova, "The Research competence of future engineers-teachers", V International ScientificPractical Conference Professional Development of Personality: Problems and Perspectives, Khmelnytskyi, 2009, s. 144-148 (in Ukrainian).

[3]. L. I. Bondarenko, The Development of Research Competence of Future Teachers of Higher Educational Institutions: Method. rivers for the presentation. higher educators closed graduate students, graduate students. Luhansk: Vyd-vo DZ "LNU im. Tarasa Shevchenka", 2013, s. 56 (in Ukrainian).

[4]. M. S. Holovan, "Model of formation of research competence of future specialists in the process of professional training", Pedahohichni nauky: teoriia, istoriia, innovatsiini tekhnolohii, № 5 (23), s. 196205, 2012 (in Ukrainian).

[5]. S. U. Honcharenko, Pedagogical research. Methodological Advice for Young Scientists: A Guidebook. Kyiv-Vinnytsia: DOV «Vinnytsia», 2008, s. 278 (in Ukrainian). 
[6]. S. O. Sysoieva, ta T. Ye. Krystopchuk, Methodology of scientific and pedagogical research: A textbook. Rivne: Volynski oberehy, 2013, s. 360 (in Ukrainian).

[7]. C. Pickering, and J. Byrne, "The benefits of publishing systematic quantitative literature reviews for $\mathrm{PhD}$ candidates and other early-career researchers", Higher Education Research \& Development, vol. 33, No. 3, pp. 534-548, 2014 (in English).

[8]. M Reguero, J. Carvajal, M. García, and M. Valverde, Good Practices in Doctoral Supervision: Reflections from the Tarragona Think Tank. Publicacions Universitat Rovira i Virgili, 2017.

[9]. L. McAlpine, Ch. Amundsen, Identity-Trajectories of Early Career Researchers: Unpacking the PostPhD Experience. Springer, 2017 (in English).

[10]. B. Durette, M. Fournier, and M. Lafon, "The core competencies of PhDs", Studies in Higher Education. vol. 41 (8), pp. 1355-1370, doi/full/10.1080/03075079.2014.968540, 2014 (in English).

[11]. V. Yu. Bykov, O. M. Spirin, ta M. P. Shyshkina, "Corporate information systems for scientificeducational activity support with the use of the cloud based services", Zb. nauk. pr.: Problemy ta perspektyvy formuvannia natsionalnoi humanitarno-tekhnichnoi elity, Vyp. 43 (47), ch. 2, s. 178-206, 2015 (in Ukrainian).

[12]. Verkhovna Rada Ukrainy (2015, Lyst. 26). Law of Ukraine No. 848-VIII, On Scientific and ScientificTechnical Activity (with amendments, dated 01.01.2017, basis № 1774-19, № 1801-19). [online]. Available: http://zakon3.rada.gov.ua/laws/show/848-19 (in Ukrainian).

[13]. Verkhovna Rada Ukrainy (2013, Sich. 24). Regulations on the upgrading of qualifications and internship of pedagogical and scientific-pedagogical workers of higher educational institutions No. 48, approved by order MONmolodsportu Ukrainy [online]. Available: http://zakon3.rada.gov.ua/laws/show/z0488-13 (in Ukrainian).

[14]. D. Jackson, "Completing a PhD by publication: a review of Australian policy and implications for practice", $\quad$ ECU Publications, 2013. [Online]. Available: http://ro.ecu.edu.au/cgi/viewcontent.cgi?article=1014\&context=ecuworks. Accessed on 25 Oct. 2018 (in English).

[15]. S. Carretero, R. Vuorikari, and Y. Punie, DigComp 2.1: The Digital Competence Framework for Citizens with eight proficiency levels and examples of use. Publications Office of the European Union EUR 28558 $\mathrm{EN},-2017$. [Online]. Available:

http://publications.jrc.ec.europa.eu/repository/bitstream/JRC106281/web-digcomp2.1pdf__ (online).pdf. Accessed on 28 Oct. 2018 (in English).

[16]. S. Albagli, M. L. Maciel, and A. H. Abdo, Open Science, open issues. Rio de Janeiro: Unirio, Brasília: IBICT, 2015. [Online]. Available: https://www.academia.edu/15431919/Open_Science_Open_Issues. Accessed on: 30 Oct. 2018 (in English).

[17]. P. Suber, "Open Access Overview". Retrieved Nov. 29, 2014. [Online]. Available: https://legacy.earlham.edu/ peters/fos/overview.htm. Accessed on 20 Oct. 2018 (in English).

[18]. R. Light, P. E. David, and K. Borner, "Open Data and Open Code for Big Science of Science Studies". Retrieved July 2013. [Online]. Available: https://www.researchgate.net/publication/257199876_Open_Data_and_Open_Code_for_Big_Science_of _Science_Studies. Accessed on: 12 Oct. 2018 (in English).

[19]. S. R. Auer, C. Bizer, G. Kobilarov, J. Lehmann, R. Cyganiak, and Z. Ives, "DBpedia: A Nucleus for a Web of Open Data". The Semantic Web. Lecture Notes in Computer Science. 4825, pp. 722-735, doi:10.1007/978-3-540-76298-0_52, 2007(in English).

[20]. J. Priem, P. Groth, and D. Taraborelli, ed. Ch. A. Ouzounis, "The Altmetrics Collection", PLoS ONE. vol. 7 (11): e48753, doi:10.1371/journal.pone.0048753, 2012 (in English).

[21]. N. S. Harinarayana, "Data Sources and Software Tools for Bibliometric Studies". [Online]. Available: https://epgp.inflibnet.ac.in/epgpdata/uploads/epgp_content/library_and_information_science/informetrics _\&_scientometrics/data_sources_and_software_tools_for_bibliometric_studies/et/333_et_m2.pdf. Accessed on: 12 Oct. 2018 (in English).

[22]. V. Weigert, "Towards Full-Text Based Research Metrics: Exploring Semantometrics". Library \& Scholarly Futures. JISC (Joint Information Systems Committee). Retrieved Aug. 19, 2016. [Online]. Available: http://repository.jisc.ac.uk/6376/1/Jisc-semantometrics-experiments-report-final.pdf. Accessed on: 12 Oct. 2018 (in English).

[23]. M. Thelwall, Introduction to Webometrics: Quantitative Web Research for the Social Sciences. Morgan \& Claypool, doi.org/10.2200/S00176ED1V01Y200903ICR004, 2009 (in English).

[24]. L. Egghe, "Expansion of the field of informetrics: origins and consequences", Information Processing \& Management, vol. 41, № 6, pp. 1311-1316, 2005 (in English).

\section{(c) BY-NC-SA}

This work is licensed under Creative Commons Attribution-NonCommercial-ShareAlike 4.0 International License 